\title{
Fortification of beef burger with the addition of bee pollen from Apis mellifera $\mathrm{L}$.
}

\author{
Leila Fernanda Serafini Heldt', Daiane Pereira', Bianca Rodrigues Souza ${ }^{2}$, \\ Ligia Bicudo Almeida-Muradian², Solange Teresinha Carpes ${ }^{1 *}$
}

${ }^{1}$ Department of Chemistry, Federal University of Technology - Paraná (UTFPR), 85503-390, Pato Branco, PR, Brazil, ${ }^{2}$ Department of Food and Nutrition, University of São Paulo, São Paulo, SP, Brazil

\section{A B S TR A C T}

The effect of adding bee pollen in beef burger on the oxidative stability was investigated. Antioxidant properties, chemical composition and vitamins were also determined. The antioxidant activity of bee pollen by DPPH (2,2-diphenyl-1-picrylhydrazyl) radical-scavenging and $\beta$-carotene-linoleic acid methods were high. The predominant minerals in bee pollen were $\mathrm{Mg}$, followed by $\mathrm{Ca}, \mathrm{K}$ and $\mathrm{Mn}$. Bee pollen can be considered a rich source of B6 vitamin $(4.96 \mathrm{mg} / 100 \mathrm{~g}$ bee pollen) and the concentrations of vitamin B1 and B2 were $0.74 \mathrm{mg} / 100 \mathrm{~g}$ and $0.78 \mathrm{mg} / 100 \mathrm{~g}$, respectively. Regarding lipid oxidation of beef burgers, assessed by thiobarbituric acid reactive substances (TBARS), it value increased at $2.09 \mathrm{mg}$ malondialdehyde/kg of beef burger after 42 days storage at $-12{ }^{\circ} \mathrm{C}$. Beef burgers containing bee pollen extract inhibited $31.78 \%$ of lipid oxidation at the end of the experiment. Thus, the strong anti-oxidative effect and high nutritive value of bee pollen suggests its potential application as natural antioxidant in meat products.

Keywords: Lipid oxidation; Antioxidant; Vitamin B; Meat product

\section{INTRODUCTION}

Lipid oxidation in meat products is the main cause of quality reduction and may affect the shelf life of the product by impairing its consumption. However, the consumers are concerned about their health and increasingly demanding for products free of food additives. Therefore, natural antioxidant compounds are often added to foods to prolong the shelf life and prevent damage caused by lipid oxidation.

In addition, natural antioxidants use may prove useful in reducing off-flavors in meat products, which are more prone to oxidative rancidity (Pérez-Fons et al., 2010). Thus, the natural products used as additives in food are gaining more attention (Rather et al., 2016; Arruda et al., 2013) mainly, due interesting antioxidant properties attributed to the presence of phenolic compounds. In fact, many studies have examined the effect of phenolic compounds found in plants extracts (Chen et al., 2014), herbs (Pérez-Fons et al., 2010), fruit by-products (Almeida et al., 2015) and apicultural products (Anjos et al., 2019; Almeida et al., 2017; Zuluaga et al., 2016) on food technology.
Bee pollen is a product harvested by bees and is the main source of nutrients for bee colonies such as proteins, minerals, carbohydrates and lipids (Sattler et al., 2015; DeMelo et al., 2016). Bee pollen has gained increasing attention for its antioxidant capacity (Morais et al., 2011) and has been used as food supplement and additives in foods (Almeida et al., 2017), due to its therapeutic properties providing benefits to human health (Arruda et al., 2013; Kostić et al., 2015; Ares et al., 2018). However, the chemical content of bee pollen, apart from phenolic compounds with antioxidant activity, may also contain other compounds with health-promoting effects such as minerals, lipids and vitamins (Arruda et al., 2013). Anjos et al. (2019) suggests that bee pollen may be used as natural alternative to prevent lipid oxidation in black pudding produced in Portugal and can improve the product quality and consumer acceptance. In fact, the use of lyophilized bee pollen in refrigerated fresh pork sausages was evaluated previously by Almeida et al. (2017).

In this way, the aim of this study was to evaluate the ability of bee pollen extract as natural antioxidant in beef burger

\footnotetext{
*Corresponding author:

Solange T. Carpes, Department of Chemistry, Federal University of Technology - Paraná (UTFPR), 85503-390, Pato Branco, PR, Brazil.

Tel.: +55 46322025 96. E-mail: carpes@utfpr.edu.br
}

Received: 02 May 2019; $\quad$ Accepted: 11 November 2019 
during processing and frozen storage. Additionally, the physicochemical composition, such as minerals, B complex vitamin, total phenolic compounds, and antioxidant properties of bee pollen extract from Apis mellifera L. were also determined.

\section{MATERIAL AND METHODS}

\section{Chemicals}

Thiobarbituric acid, Folin-Ciocalteu phenol reagent acid were purchased from Vetec (São Paulo, Brazil). Trichloroacetic acid (TCA), thiamine hydrochloride, pyridoxol hydrochloride, pyridoxal hydrochloride, pyridoxamine dihydrochloride, niacin, niacinamide, $\mathrm{DPPH}$ (2,2-diphenyl-1-picrylhydrazyl), ABTS •+ (2,2'-azino-di(3ethylbenzthiazoline-6-sulphonic acid), TPTZ (2,4,6-Tri(2pyridyl)-s-triazine), linoleic acid, $\beta$-carotene were obtained from Sigma-Aldrich (Sternheim, Germany). All reagents used were of analytical grade.

\section{Bee pollen and preparation of the extracts}

Samples of bee pollen from Apis mellifera $\mathrm{L}$. were collected in apiaries of Paraná State, southern Brazil. Samples were dried in an oven with heating at $40{ }^{\circ} \mathrm{C}$, ground and stored in a freezer at $-12{ }^{\circ} \mathrm{C}$. Samples containing $10 \mathrm{~g}$ of bee pollen (dry basis) were extracted with $100 \mathrm{~mL}$ of ethanol solution $(800 \mathrm{~g} / \mathrm{L})$ in a shaker (SL 222, São Paulo, Brazil) at $40{ }^{\circ} \mathrm{C}$ for $60 \mathrm{~min}$ at a stirring rate of $150 \mathrm{rpm}$. The extract was filtered, the supernatant was evaporated in a rotary evaporator (Fisatom 802, São Paulo, Brazil) (vacuum pressure of $600 \mathrm{~mm} \mathrm{Hg}$ and $40^{\circ} \mathrm{C}$ ) and lyophilized (Liotop L101, São Carlos, Brazil).

\section{Macronutrients}

The water content (moisture), ash, protein, lipid, fiber and total sugar were determined according to AOAC (2005). All analyses were performed in triplicate and dry basis.

\section{Mineral content}

An spectrophotometer - Varian Model Spectra AA 100 \& 200 was used to determine the concentrations of ferro $(\mathrm{Fe})$, calcium $(\mathrm{Ca})$, zinc $(\mathrm{Zn})$, potassium $(\mathrm{K})$, sodium $(\mathrm{Na})$, copper $(\mathrm{Cu})$, magnesium $(\mathrm{Mg})$ and manganese $(\mathrm{Mn})$ in accordance with the methodology described by AOAC (2000). The values obtained were expressed as $\mathrm{mg}$ of mineral $/ \mathrm{g}$ bee pollen. The assay was performed in triplicate.

\section{Chromatographic analysis of the B complex vitamin}

The chromatography system was equipped with two Shimadzu (LC-20AT) pumps, Shimadzu (SIL-20A Autosampler) autosampler, Shimadzu (RF-10AXL), Fluorescence detector, Software LC-Solution. The extraction condition and operating parameters of the equipment used to determine the values of vitamin B1, vitamin B2, vitamin PP (niacin and niacinamide vitamers), and vitamin B6 (pyridoxol, pyridoxal and pyridoxamine vitamers) were performed as described by previous methods (Arruda et al., 2013). Values were reported as mg of vitamin/100 $\mathrm{g}$ of bee pollen. The assay was performed in triplicate.

\section{Total phenolic contents (TPC)}

The TPC were quantified by Folin-Ciocalteu method using gallic acid as standard and UV/Vis spectrophotometer (Bel Photonics 2000, Piracicaba, Brazil), at $740 \mathrm{~nm}$ (Singleton et al., 1999). The results were expressed as $\mathrm{mg} \mathrm{GAE} / \mathrm{g}$ of sample (GAE: Gallic Acid Equivalent).

\section{Antioxidant activities}

Four methods were used to determine the antioxidant capacity of the bee pollen: DPPH and ABTS radicalscavenging, oxidation of $\beta$-carotene/linoleic acid and FRAP (Ferric reducing antioxidant power) methods. The DPPH free radical scavenging activity was realized according to Brand-Williams et al. (1995) and the results were expressed as $\mathrm{EC}_{50}$, equivalent concentration of the extracts required to obtain a $50 \%$ antioxidant effect $(\mu \mathrm{g} / \mathrm{mL})$. ABTS assay was performed according to Re et al. (1999) and the results were expressed as $\mu \mathrm{mol}$ TEAC/g of bee pollen (TEAC: Trolox equivalent antioxidant capacity). Coupled oxidation of $\beta$-carotene and linoleic acid was determined by Ahn et al. (2007) and the results were expressed as percent inhibition relative to control sample. In addition, the FRAP method was performed as described by Pulido et al. (2000) and the results were expressed as $\mu \mathrm{mol}$ of $\mathrm{Fe}^{+2} / \mathrm{g}$ of pollen. All tests were carried out in triplicate.

\section{Beef burger elaboration and lipid oxidation assay by TBARS}

The fresh meat $(750 \mathrm{~g} / \mathrm{Kg})$ was minced and homogenized with soy protein $(40 \mathrm{~g} / \mathrm{Kg})$, iced water $(85 \mathrm{~g} / \mathrm{Kg})$, lard $(103 \mathrm{~g} / \mathrm{Kg})$, salt $(15 \mathrm{~g} / \mathrm{Kg})$, monosodium glutamate $(2 \mathrm{~g} / \mathrm{Kg})$, grounded with spices such as white pepper, garlic powder and onion powder (all $2 \mathrm{~g} / \mathrm{Kg}$ ). The mixture was divided into 3 lots. No additional ingredient was included in the control lot (T1). A batch containing $0.1 \mathrm{~g} / \mathrm{Kg}$ of BHT (butylated hydroxytoluene) was prepared (T2). The last lot received lyophilized bee pollen extract at a concentration of $0.1 \mathrm{~g} / \mathrm{Kg}$ (T3). The beef burgers were moulded at a mean weight of $100 \mathrm{~g}$, packed and stored at $-12{ }^{\circ} \mathrm{C}$ for 42 days. The beef burgers lipid oxidation was evaluated at times $0,7,14,21,28,35$ and 42 days of storage at $-12{ }^{\circ} \mathrm{C}$ by TBARS method (Raharjo et al., 1992). $1,1,3,3$ tetramethoxypropane (TMP) was used as reference standard $(0.6$ to $3.0 \mu \mathrm{mol} / \mathrm{L})$ and the TBARS values were expressed as $\mathrm{mg}$ of malondialdehyde $/ \mathrm{kg}$ sample. The assay was performed in triplicate. 


\section{Statistical analysis}

All tests were performed in triplicate and the obtained data are presented as means values \pm standard deviation. The data was evaluated by variance analysis (ANOVA) and the averages were compared by Tukey and $t$ test, with significant differences at $\mathrm{p}<0.05$, using the $\mathrm{R}$ Comander software version 3.0.2 (2013).

\section{RESULTS AND DISCUSSION}

\section{Macronutrients and minerals of bee pollen}

The macronutrients composition of bee pollen is described in Table 1. The values obtained were compared with the requirements prescribed in the Brazilian legislation (Brasil 2001) to ensure that the pollen produced complies with the current norms. The water content of bee pollen showed an average value of $7.44 \pm 0.01 \mathrm{~g} / 100 \mathrm{~g}$ bee pollen. This value was above the upper limits $(4 \mathrm{~g} / 100 \mathrm{~g})$ allowed in Brasil (2001) and could be attributed to inadequate drying process of bee pollen or storage conditions (Kostić et al., 2015). The variability in the water content in bee pollen can be due to its high hygroscopicity and can be influenced by the type of package used and by the storage conditions such as temperature and relative humid atmosphere.

The average ash content was $2.22 \mathrm{~g} / 100 \mathrm{~g}$ (Table 1). These results are similar to those found in previous studies reported by Arruda et al. (2013), who obtained $2.98 \%$ of ash in bee pollen. The average total protein and lipid

$\begin{aligned} & \text { Table 1: Macronutrients and minerals of bee pollen produced } \\
& \text { by Apis mellifera } \mathrm{L} \text {. }\end{aligned}$
\begin{tabular}{lc}
\hline Analysis & $\mathbf{( g / 1 0 0 ~} \mathbf{g})$ \\
\hline Water content & $7.44 \pm 0.23$ \\
Ash & $2.22 \pm 0.04$ \\
Protein $(\mathrm{N} \times 6.25)$ & $21.35 \pm 0.01$ \\
Lipids & $4.64 \pm 0.01$ \\
Fibers & $4.36 \pm 0.06$ \\
Total sugars & $15.50 \pm 0.08$ \\
Fe & $0.005 \pm 0.00$ \\
$\mathrm{Na}$ & $0.036 \pm 0.00$ \\
$\mathrm{~K}$ & $0.36 \pm 0.02$ \\
$\mathrm{Ca}$ & $1.12 \pm 0.03$ \\
$\mathrm{Mg}$ & $1.21 \pm 0.05$ \\
$\mathrm{Zn}$ & $0.05 \pm 0.01$ \\
$\mathrm{Cu}$ & $0.08 \pm 0.01$ \\
$\mathrm{Mn}$ & $0.17 \pm 0.02$ \\
\hline $\mathrm{Va}$
\end{tabular}

Values of triplicate means \pm standard deviation $(n=3)$. contents was $21.35 \mathrm{~g} / 100 \mathrm{~g}$ and $4.64 \mathrm{~g} / 100 \mathrm{~g}$, respectively (Table 1). In 2013, Arruda et al. (2013) reported lipid contents even higher $(5.39 \mathrm{~g} / 100 \mathrm{~g})$ than the results found in our study.

The bee pollen showed $15.5 \mathrm{~g} / 100 \mathrm{~g}$ of total sugars, and was the second most abundant component in bee pollen (Table 1). The sugar content in the bee pollen may be justified by the presence of honey and/or nectar from the flowers visited by the bees and represent important component of bee pollen from the nutritional and energetic point of view (Kostić et al., 2015). Moreover, the high contents of protein and reducing sugars and the low contents of lipids make the bee pollen an excellent food supplement (Table 1).

The predominant minerals in the bee pollen was $\mathrm{Mg}$, followed by $\mathrm{Ca}, \mathrm{K}$ and $\mathrm{Mn}$ (Table 1). The mineral composition of the bee pollen is affected by the plant origin, and also the growth conditions, such soil and geographical origin. According to Silva et al. (2012) who found $\mathrm{Cu}, \mathrm{Mn}, \mathrm{P}$ and $\mathrm{Zn}$ in the soil, plant and bee pollen from northern Brazil (Piauí State), and there are translocation of minerals from the soil to the bee pollen. The bee pollen from southern Brazil has great botanical diversity due the subtropical to tropical climate, which provide greater richness in its nutritional composition (Sattler et al., 2015).

According to Brasil (2005), which regulates the Recommended Daily Ingestion (RDI) of protein, vitamins and minerals for food to be considered as a source or rich in a specific micronutrient, it should be present at $15 \%$ and $30 \%$ of the total, respectively. $25 \mathrm{~g}$ of bee pollen is the recommended daily intake for the consumption of bee pollen according to Bastos et al. (2003). Therefore, the bee pollen analyzed in this study can be considered sources of $\mathrm{Mn}$ and $\mathrm{Cu}$, rich in $\mathrm{Mg}$, $\mathrm{Ca}$ and $\mathrm{K}$.

\section{Vitamin analysis}

In this study, the presence of vitamin $\mathrm{B}_{1}$ (thiamine), $\mathrm{B}_{2}$ (riboflavin), three vitamers of vitamin $\mathrm{B}_{6}$ (pyridoxamine and pyridoxal groups, pyridoxol) and two vitamers of vitamin PP (nicotinic acid and nicotinamide) were detected in bee pollen (Table 2). The concentrations of vitamin B1 and B2 were $0.74 \mathrm{mg} / 100 \mathrm{~g}$ and $0.78 \mathrm{mg} / 100 \mathrm{~g}$, respectively. These results are in agreement with Arruda et al. (2013), who

Table 2: Concentrations of vitamins $\mathrm{B}_{1}, \mathrm{~B}_{2}, \mathrm{PP}$ and $\mathrm{B}_{6}$ (including its vitamers) of bee pollen produced by Apis mellifera $\mathrm{L}$.

\begin{tabular}{|c|c|c|c|c|c|c|c|c|c|}
\hline & \multirow{2}{*}{$\begin{array}{l}\text { Vitamin } \mathrm{B}_{1} \\
(\mathrm{mg} / 100 \mathrm{~g})\end{array}$} & \multirow{2}{*}{$\begin{array}{l}\text { Vitamin } B_{2} \\
(\mathrm{mg} / 100 \mathrm{~g})\end{array}$} & \multicolumn{3}{|c|}{ Vitamin PP (mg/100 g) } & \multicolumn{4}{|c|}{ Vitamin $B_{6}(\mathrm{mg} / 100 \mathrm{~g})$} \\
\hline & & & $\begin{array}{l}\text { Nicotinic } \\
\text { acid }\end{array}$ & Nicotinamide & $\begin{array}{c}\text { Niacin } \\
\left(\text { Vitamin } \mathrm{B}_{3}\right)\end{array}$ & Pyridoxol & Pyridoxal & Pyridoxamine & Pyridoxine \\
\hline $\begin{array}{l}\text { Bee } \\
\text { pollen }\end{array}$ & $0.74 \pm 0.02$ & $0.78 \pm 0.04$ & $0.84 \pm 0.07$ & $4.62 \pm 0.07$ & $5.46 \pm 0.14$ & $0.14 \pm 0.00$ & $4.34 \pm 0.08$ & $0.48 \pm 0.17$ & $4.96 \pm 0.25$ \\
\hline
\end{tabular}

Values of triplicate means \pm standard deviation $(n=3)$. 
analyzed seven dehydrated pollen samples from São Paulo State, Brazil, and reported average values of $0.64 \mathrm{mg} / 100 \mathrm{~g}$ and $0.60 \mathrm{mg} / 100 \mathrm{~g}$ for vitamins B1 and B2, respectively.

According to Brasil (2005), the recommended daily intake (RDI) of vitamins B1 and B2 are respectively 1.2 and $1.3 \mathrm{mg} /$ day. According Arruda et al. (2013), to be considered a source and rich in a specific nutrient, the food must be found in quantities corresponding to $15 \%$ and $30 \%$ of the portion size, respectively. Since bee pollen presents, more than $15 \%$ of the RDI of vitamin B1 and B2 it can be considered a source of vitamin B1 and B2 (Table 2).

The concentration of vitamin B3 (niacin) in the bee pollen, considering its two vitamers (nicotinic acid and nicotinamide) was $5.46 \mathrm{mg} / 100 \mathrm{~g}$ and this bee pollen can't be considered source of niacin, which has RDI of $16 \mathrm{mg} /$ day for adults (Table 2). The vitamin B3 value found in this study was lower than found by Arruda et al. (2013), who analyzed seven bee pollen samples from São Paulo and reported an average of $12.18 \mathrm{mg} / 100 \mathrm{~g}$ of vitamin $B_{3}$. However, the value found for vitamin $B_{6}$ was $4.96 \mathrm{mg} / 100 \mathrm{~g}$, which its RDI is $1.3 \mathrm{mg} /$ day (Brasil 2005). Therefore, the bee pollen can be considered rich in pyridoxine (Vitamin $\mathrm{B}_{6}$ ) since they contained amount higher than $30 \%$ of the RDI. This value was higher than the average means $(0.55 \mathrm{mg} / 100 \mathrm{~g})$ for pyridoxine in bee pollen obtained by Arruda et al. (2013). The differences in chemical composition of bee pollen is attributed mainly to the different botanical species and geographical origin, as well as climate and soil type (Sattler et al., 2015).

\section{Total phenolic compounds and antioxidant activities}

Phenolic compounds may directly contribute to the antioxidant action due to its redox properties that allow to act as reducing agents, hydrogen donors and oxygen singlet. The average content of total phenolic compounds (TPC) determined by the Folin-Ciocalteu method, for the bee pollen was 18.79 $\pm 0.08 \mathrm{mg}$ GAE/g of pollen (Table 3). The phenolic compounds content were superior to those found by Morais et al. (2011) who found values that ranged from 10.5 to $16.8 \mathrm{mg}$ of $\mathrm{mg}$ GAE/g of bee pollen from five Portuguese Natural-Parks.

The diversity of the total phenolic in bee pollen when compared to other studies may be associated to different extraction conditions and solvent type used. In addition, the environmental conditions and the geographic origin of the bee pollen also are important factors to be analyzed. The bee pollen have different nutritional significance but the phenolic compounds are one of the most critical ingredients related their antioxidant activity (Morais et al., 2011).

There are various methods available in the assessment of antioxidant capacity of bee pollen extracts. In this study, we used four methods for antioxidant capacity assay with different mechanism of action: indirect methods as DPPH, ABTS, and FRAP and direct method as coupled oxidation of $\beta$-carotene and linoleic acid assay. The results of antioxidant activity of bee pollen extract from different methods are summarized in Table 3. The scavenger activity of free radical DPPH was expressed in terms of $\mathrm{EC}_{50}$. Lower values indicates better antioxidant capacity of bee pollen extract. The radical DPPH is widely used to test the free radical scavenger capacity in apicultural products such as, bee pollen (Mărgăoan et al., 2014; Almeida et al., 2017), propolis (Calegari et al., 2017) and honey (Chua et al., 2013). The value of $\mathrm{EC}_{50}$ for the bee pollen extract was $0.86 \pm$ $0.15 \mathrm{mg} / \mathrm{mL}$ (Table 3). The result obtained in the present study was better than observed by Morais et al. (2011), who found in bee pollen from Portugal values ranged from 2.16 to $5.87 \mathrm{mg} / \mathrm{mL}$.

Probably the greater stability and solubility of ABTS radical in water and organic solvents allow the determination of antioxidant capacity of both hydrophilic and lipophilic compounds (Floegel et al., 2013). The bee pollen extract showed antioxidant activity by ABTS assay equivalent of $161.10 \pm 0.35 \mu \mathrm{mol}$ TEAC/g bee pollen (Table 3$)$. In this study was found lower antioxidant activity than reported by Mărghitas et al. (2009) who found in Salix sp. bee pollen from Romania values of $6.84 \mathrm{mmol} \mathrm{TEAC} / \mathrm{g}$.

Some previous studies have also reported that the iron reducing power may serve as an important indicator of potential antioxidant activity in apicultural products (Mărgăoan et al., 2014; Krystyjan et al., 2015). In our study, the ferric reducing ability of bee pollen extract revealed a good FRAP activity $\left(71.34 \pm 0.42 \mathrm{mmol} \mathrm{Fe}^{2+} / \mathrm{g}\right.$ ) (Table 3) and was higher than previously reported by Mărgăoan et al. (2014), who achieved values ranging from 0.38 to 3.17 $\mathrm{mmol} \mathrm{Fe} \mathrm{F}^{2+} / \mathrm{g}$ in bee pollen from Transylvania.

The antioxidant activity by $\beta$-carotene bleaching method may be useful especially in the investigation of lipophilic antioxidants such as plants extract, essential oils, honey and propolis (Ahn et al., 2007; Rodríguez-Rojo et al., 2012;

Table 3: Total phenolic compounds and antioxidant activity of bee pollen extract measured by different methods

\begin{tabular}{|c|c|c|c|c|c|}
\hline Sample & $\begin{array}{c}\text { Total phenolic } \\
\text { compound+(mg GAE/g) }\end{array}$ & $\begin{array}{l}\text { DPPH }\left(E C_{50}\right) \\
(\mathrm{mg} / \mathrm{mL})\end{array}$ & ABTS $(\mu \mathrm{mol}$ TEAC/g) & $\begin{array}{c}\beta \text {-carotene/linoleic } \\
(\%)\end{array}$ & $\mathrm{FRAP}+\left(\mathrm{mmol}\right.$ de $\left.\mathrm{Fe}^{2+} / \mathrm{g}\right)$ \\
\hline Bee pollen extract & $18.79 \pm 0.08$ & $0.86 \pm 0.15$ & $161.10 \pm 0.35$ & $89.88 \pm 0.12$ & $71.34 \pm 0.42$ \\
\hline
\end{tabular}

$\mathrm{EC}_{50}$ : Equivalent concentration; TEAC: Trolox-equivalent antioxidant capacity 
Heldt, et al.

Table 4: Average values of TBARS ( $\mathrm{mg}$ of malondialdehyde/ $\mathrm{kg}$ of meat) in beef burgers treatments during storage at $-12^{\circ} \mathrm{C}$

\begin{tabular}{lccccccc}
\hline Treatments & $\mathbf{0}$ days & $\mathbf{7}$ days & $\mathbf{1 4}$ days & $\mathbf{2 1}$ days & $\mathbf{2 8}$ days & $\mathbf{3 5}$ days & $\mathbf{4 2}$ days \\
\hline $\mathrm{T}_{1}$ & $1.26 \pm 0.04^{\mathrm{Ga}}$ & $1.29 \pm 0.03^{\mathrm{Fa}}$ & $1.61 \pm 0.03^{\mathrm{Ea}}$ & $1.77 \pm 0.02^{\mathrm{Da}}$ & $1.85 \pm 0.05^{\mathrm{Ca}}$ & $1.96 \pm 0.02^{\mathrm{Ba}}$ & $2.36 \pm 0.03^{\mathrm{Aa}}$ \\
$\mathrm{T}_{2}$ & $1.20 \pm 0.01^{\mathrm{Fb}}$ & $1.20 \pm 0.02^{\mathrm{Fb}}$ & $1.55 \pm 0.03^{\mathrm{Eb}}$ & $1.64 \pm 0.04^{\mathrm{Db}}$ & $1.66 \pm 0.02^{\mathrm{Cb}}$ & $1.71 \pm 0.03^{\mathrm{Bb}}$ & $2.30 \pm 0.04^{\mathrm{Ab}}$ \\
$\mathrm{T}_{3}$ & $1.12 \pm 0.02^{\mathrm{Gc}}$ & $1.15 \pm 0.01^{\mathrm{Fc}}$ & $1.32 \pm 0.03^{\mathrm{EC}}$ & $1.42 \pm 0.02^{\mathrm{Dc}}$ & $1.49 \pm 0.03^{\mathrm{Cc}}$ & $1.54 \pm 0.03^{\mathrm{BC}}$ & $1.61 \pm 0.04^{\mathrm{AC}}$ \\
Average & $1.19 \pm 0.02^{\mathrm{F}}$ & $1.21 \pm 0.02^{\mathrm{F}}$ & $1.49 \pm 0.03^{\mathrm{E}}$ & $1.61 \pm 0.03^{\mathrm{D}}$ & $1.67 \pm 0.03^{\mathrm{C}}$ & $1.74 \pm 0.02^{\mathrm{B}}$ & $2.09 \pm 0.04^{\mathrm{A}}$ \\
\hline
\end{tabular}

TBARS: Thiobarbituric acid reactive substances content; $\mathrm{T}_{1}$ : Control (no added antioxidant); $\mathrm{T}_{2}$ : Treatment with $0.1 \mathrm{~g} / \mathrm{kg}$ BHT (butylated hydroxytoluene); $\mathrm{T}_{3}$ : Treatment added with $0.1 \mathrm{~g} / \mathrm{Kg}$ of bee pollen extract; Different lower-case letter in the same column indicate significant difference $(p<0.05)$ by Tukey's test. Different capital letters in the same row indicate significant difference $(\mathrm{p}<0.05)$ by Tukey's test. Values are presented as mean \pm standard deviation $(n=3)$.

Table 5: Percent decrease in TBARS values in beef burgers treated with $\mathrm{BHT}$ and Bee pollen extract, during storage at $-12^{\circ} \mathrm{C}$

\begin{tabular}{lccccccc}
\hline & Treatment & \multicolumn{7}{c}{$\begin{array}{c}\text { Percent decrease in TBARS compared to control } \\
\left(\mathrm{T}_{1}\right)^{\mathrm{a}}\end{array}$} \\
\cline { 2 - 8 } & \multicolumn{6}{c}{ Storage time (days) } \\
\cline { 2 - 8 } & $\mathbf{0}$ & $\mathbf{7}$ & $\mathbf{1 4}$ & $\mathbf{2 1}$ & $\mathbf{2 8}$ & $\mathbf{3 5}$ & $\mathbf{4 2}$ \\
\hline $\mathrm{T}_{2}$ & 4.76 & 6.98 & 3.73 & 7.34 & 10.27 & 12.76 & 2.54 \\
$\mathrm{~T}_{3}$ & 11.11 & 10.85 & 18.01 & 19.77 & 19.46 & 21.43 & 31.78 \\
\hline
\end{tabular}

aData not statistically analysed, but percentages were computed from the statistical data in Table 1.

$\mathrm{T}_{1}$ : Treatment control (no added antioxidant); $\mathrm{T}_{2}$ : Treatment with $0.1 \mathrm{~g} / \mathrm{kg}$ BHT (butylated hydroxytoluene); $\mathrm{T}_{3}$ : Treatment added with $0.1 \mathrm{~g} / \mathrm{Kg}$ of bee pollen extract

Mărgăoan et al., 2014). The bee pollen extract showed $89.88 \%$ of inhibition by the $\beta$-carotene method (Table 3 ). This result obtained in the present study was slightly higher than the observed by Leja et al. (2007), who investigated the antioxidant properties by beta-carotene method in 12 bee pollen samples from Krakow region (Poland) and found values ranged from 0.8 to $86.4 \%$ inhibition of lipid peroxidation.

The antioxidant activity results of bee pollen extract by four methods demonstrated that bee pollen possesses good activity, suggesting that it could be useful in oxidative deterioration inhibition in food products. According to Morais et al. (2011), the antioxidant activity of bee pollen is largely because the phenolic acid and flavonoids have free radical scavenger activity. Although other constituents such as, proteins and vitamins may contribute to this property. In addition, according to Li et al. (2018) the bee pollen is a nutrient-rich treasure trove of active natural metabolites and increasing the diversity of bee pollen-based food products can promote future industrial developments as well as knowledge of this important functional food.

\section{Effect of bee pollen extract on oxidative stability in beef burgers}

The lipid oxidation of beef burger was affected by storage time; it increased, on average, from $1.19 \mathrm{mg}$ to $2.09 \mathrm{mg}$ malondialdehyde/kg of beef burger (Table 4). Treatment with bee pollen showed lower $(\mathrm{p}<0.05)$ TBARS values during any day of storage than the control and BHT treatments.

After fourteen days of storage, the samples treated with bee pollen extract had lower TBARS values in comparison with the treatment lot T1 and lot T2 (Table 4). At this point, the bee pollen extract inhibited $18.01 \%$ of lipid oxidation in the beef burger and had significantly lower values of TBARS values compared to the beef burger lot T1 (Table 5).

It was possible to see that the TBARS values increased over 42 days of storage in treatment with and without synthetic antioxidant. The highest content of malondialdehyde was found in beef burgers without antioxidants - lot T1 (2.36 $\pm 0.03 \mathrm{mg}$ of malondialdehyde $/ \mathrm{Kg}$ of meat) and with BHT $-\operatorname{lot} \mathrm{T} 2(2.30 \pm 0.04 \mathrm{mg}$ of malondialdehyde $/ \mathrm{Kg}$ of meat) after 42 days of the storage. In addition, these treatments had a significant difference $(p<0.05)$ between the beef burgers containing bee pollen extract $(1.61 \pm 0.04 \mathrm{mg}$ of malondialdehyde $/ \mathrm{Kg}$ of meat). At the end of storage time (42 days), the bee pollen extract inhibited $31.78 \%$ of lipid oxidation in comparison to the control treatment (Table 5). These findings demonstrate the effectiveness of bee pollen extract as natural antioxidant to control lipid oxidation in beef burger during storage at $-12{ }^{\circ} \mathrm{C}$.

In fact, natural products used as antioxidants are gaining more and more attention from researchers worldwide (Krystyjan et al., 2015; Almeida et al., 2017; Reis et al., 2017). In this regard, the herbs (Zhang et al., 2013), plants (Fernández-Ginés et al., 2005; Pérez-Fons et al., 2010), fruits (Rather et al., 2016), propolis (Reis et al., 2017) and bee pollen (Krystyjan et al., 2015; Almeida et al., 2017; Anjos et al., 2019) have been used as natural antioxidant and antimicrobial agents in many kinds of food. However, reports about the practical applications of bee pollen in meat production are scarce and further research is important to achieve better understanding of the subject.

Thus, the bee pollen can be considered interesting alternatives to synthetic antioxidants, and can be used to prevent the oxidation of complex food systems, as meat products. This action could contribute to the expansion of bee pollen applications and also become a more profitable activity for beekeepers. Given the fact that beef burgers are one of the most popular food in the world and the consumers are becoming increasingly aware of the relationship between diet and health, it seems advisable to undertake research on the fortify of meat products with 
bee pollen. The bee pollen addition as health-promoting substances and natural antioxidants can be an action entirely justified and innovative.

\section{CONCLUSION}

From the results obtained it was possible to indicate that bee pollen has interesting chemical composition, such as high amounts of protein and sugars and low contents of lipids. Moreover, the bee pollen can be considered a source of $\mathrm{Cu}$ and $\mathrm{Mn}$, and rich in $\mathrm{Mg}, \mathrm{Ca}, \mathrm{K}$ and $\mathrm{B} 6$ vitamin. In this study, the bee pollen shown high phenolic compounds content with antioxidant activity that can prevent the formation of free radicals. On the basis of our results, the bee pollen extract has a great inhibitory effect on lipid oxidation in beef burger, which was much more efficient than the BHT. Additionally, the B complex vitamin and minerals from bee pollen ensure beneficial effects to human health, and may be considered "super foods". This kind of raw material may be used as a substitute for synthetic antioxidant in beef burger production. The combination of antioxidant properties with nutritive value and healthpromoting effects of bee pollen suggests its potential application as food ingredient in meat products.

\section{ACNOWLEDGEMENTS}

The authors wish to thank the National Council for Scientific and Technological Development - CNPq, the Araucária Research Foundation for the scholarships and financial support. We thank for Breyer \& Cia Ldta of União da Vitória - PR, Brazil for providing the bee pollen sample.

\section{Declaration of conflicting interests}

The authors have no conflict of interest to declare.

\section{Authors' contributions}

L.F.S.H. and D.P.C. conceived and designed the research; B.R.S. validation and analyzed the data of vitamin and interpreted the data; LBAM critically reviewed the manuscript; S.T.C. conducted the research work, interpreted the data, and prepared the manuscript. All authors read and approved the final manuscript.

\section{REFERENCES}

Ahn, M. R., S. Kumazawa, T. Hamasaka, K. S. Bang and T. Nakayama. 2004. Antioxidant activity and constituents of propolis collected in various areas of Korea. J. Agric. Food Chem. 52: 7286-7292.

Almeida, J. F., A. S. Reis, L. F. S. Heldt, D. Pereira, M. Bianchin, C. Moura, M. V. Plata-Oviedo, C. W. I. Haminiuk, I. S. Ribeiro, C. F. P. Luz and S. T. Carpes. 2017. Lyophilized bee pollen extract: A natural antioxidant source to prevent lipid oxidation in refrigerated sausages. LWT Food Sci. Technol. 76: 299-305.
Almeida, P. L., S. N. Lima, L. L. Costa, C. C. Oliveira, K. A. Damasceno, B. A. Santos and P. C. Campagnol. 2015. Effect of jabuticaba peel extract on lipid oxidation microbial stability and sensory properties of Bologna-type sausages during refrigerated storage. Meat Sci. 110: 9-14.

AOAC. 2005. Official Methods of Analysis of the Association of Official Analytical Chemists: Association of Official Analytical Chemists. AOAC, Maryland.

AOAC. 2000. Official Methods of Analysis of the Association of Official Analytical Chemists. Association of Official Analytical Chemists, AOAC, Washington, DC.

Ares, A. M., S. Valverde, J. L. Bernal, M. J. Nozal and J. Bernal. 2018. Extraction and determination of bioactive compounds from bee pollen. J. Pharm. Biomed. Anal. 147: 110-124.

Arruda, V. A. S., A. A. S. Pereira, A. S. Freitas, O. M. Barth and L. B. Almeida-Muradian. 2013. Dried bee pollen: B complex vitamins physicochemical and botanical composition. J. Food Compos. Anal. 29: 100-105.

Bastos, D. H. M., C. I. Rocha, I. B. S. Cunha, P. O. Carvalho and E. A. S. Torres. 2003. Composição e qualidade de pólen apícola comercializado em algumas cidades nos estados de São Paulo e Minas Gerais Brasil. Rev. Inst. Adolfo Lutz. 62: 239-244.

Brand-Williams, W., M. E. Cuvelier and C. Berset. 1995. Use of a free radical method to evaluate antioxidant activity. LWT Food Sci. Technol. 28: 25-30.

Brasil. 2001. Normativa n.3 de 19 de Janeiro de 2001. Ministério da Saúde. Agência Nacional de Vigilância Sanitária. Available from: http://www.agricultura.gov.br. [Last accessed on 2018 Nov 14].

Brasil. 2005. Resolução RDC n. 269 de 22 de Setembro de 2005. Ministério da Saúde. Agência Nacional de Vigilância Sanitária. Available from: http://www.agricultura.gov.br. [Last accessed on 2018 Nov 14].

Calegari, M. A., A. Prasniewski, C. Silva, R. Y. Sado, F. M. C. Maia, L. M. S. Tonial and T. L. C. Oldoni. 2017. Propolis from Southwest of Parana produced by selected bees: Influence of seasonality and food supplementation on antioxidant activity and phenolic profile. Anais Acad. Brasil. Ciên. 1: 45-55.

Chen, X., Y. Zhang, Y. Zu, L. Yang, Q. Lu and W. Wang. 2014. Antioxidant effects of rosemary extracts on sunflower oil compared with synthetic antioxidants. Int. J. Food Sci. Technol. 49: 385-391.

Chua, L. S., N. L. A. Rahaman, N. A. Adnan and T. T. Eddie Tan. 2013. Antioxidant activity of three honey samples in relation with their biochemical components. J. Anal. Method. Chem. 2013: 1-8.

De-Melo, A. A. M., L. M. Estevinho, J. A. G. Sattler, B. R. Souza, A. S. Freitas, O. M. Barth and L. B. Almeida-Muradian. 2016. Effect of processing conditions on characteristics of dehydrated bee-pollen and correlation between quality parameters. LWT Food Sci. Technol. 65: 808-815.

Floegel, A., D. O. Kim, S. J. Chung, S. I. Koo and O. K. Chun. 2013. Comparison of ABTS/DPPH assays to measure antioxidant capacity in popular antioxidant-rich US foods. J. Food Comp. Anal. 24: 1043-1048.

Kostić, A. Ž., M. B. Barać, S. P. Stanojević, D. M. MilojkovićOpsenica, Z. L. Tešić, B. Šikoparija, P. Radišić, M. Prentović and M. B. Pešić. 2015. Physicochemical composition and technofunctional properties of bee pollen collected in Serbia. LWT Food Sci. Technol. 62: 301-309.

Krystyjan, M., D. Gumul, R. Ziobro and A. Korus. 2015. The fortification of biscuits with bee pollen and its effect on physicochemical and antioxidant properties in biscuits. LWT Food Sci. Technol. 63: 640-646.

Leja, M., A. Mareczek, G. Wyzgolik, J. Klepacz-Baniak and 
K. Czekonska. 2007. Antioxidative properties of bee pollen in selected plant species. Food Chem. 100: 237-240.

Li, Q., K. Wang, M. C. Marcucci, A. C. H. F. Sawaya, L. Hu, X. Xue, L. Wu and F. Hu. 2018. Nutrient-rich bee pollen: A treasure trove of active natural metabolites. J. Funct. Foods. 49: 472-484.

Mărgăoan, R., L. A. Mărghitas, D. S. Dezmirean, F. V. Dulf, A. Bunea, A. S. Socaci and O. Bobiş. 2014. Predominant and secondary pollen botanical origins influence the carotenoid and fatty acid profile in fresh honey bee-collected pollen. J. Agric. Food Chem. 62: 6306-6316.

Mărghitas, L. A., O. G. Stanciu, D. S. Dezmirean, O. Bobis, O. Popescu, S. Bogdanov and M. G. Campos. 2009. In vitro antioxidant capacity of honeybee-collected pollen of selected floral origin harvested from Romania. Food Chem. 115: 878-883.

Morais, M., L. Moreira, X. Feas and L. M. Estevinho. 2011. Honeybeecollected pollen from five Portuguese natural parks: Palynological origin phenolic content antioxidant properties and antimicrobial activity. Food Chem. Toxicol. 49: 1096-1101.

Pérez-Fons, L., M. T. Garzón and V. Micol. 2010. Relationship between the antioxidant capacity and effect of rosemary (Rosmarinus officinalis L.) polyphenols on membrane phospholipid order. J. Agric. Food Chem. 58: 161-171.

Pulido, R., L. Bravo and F. Saura-Calixto. 2000. Antioxidant of dietary polyphenols as determined by a modified ferric reducing antioxidant power assay. J. Agric. Food Chem. 48: 3396-3402.

Raharjo, S., J. N. Sofos and G. R. Schmidt. 1992. Improved speed specificity and limit of determination of an aqueous acid extraction thiobarbituric acids method for measuring lipid peroxidation in beef. J. Agric. Food Chem. 40: 2182-2185.

Rather, S. A., F. A. Masoodi, R. J. A. Akhter, Rather and K. A. Shiekh. 2016. Advances in use of natural antioxidants as food additives for improving the oxidative stability of meat products. Madridge J. Food Technol. 1: 10-17.

Re, R., N. Pellegrini, A. Oroteggente, A. Pannala, M. Yang and
C. Rice-Evans. 1999. Antioxidant activity applying an improved ABTS radical cation decolorization assay. Free Rad. Biol. Med. 26: 1231-1237.

Reis, A. S., C. Diedrich, C. Moura, D. Pereira, J. F. Almeida, L. D Silva, M. S. V. Plata Oviedo, R. A. W. Tavares and S. T. Carpes. 2017. Physico-chemical characteristics of microencapsulated propolis co-product extract and its effect on storage stability of burger meat during storage at-15 C. LWT Food Sci. Technol. 76: 306-313.

Rodríguez-Rojo, S., A. Visentina, D. Maestric and M. J. Coceroa. 2012. Assisted extraction of rosemary antioxidants with green solvents. J. Food Eng. 109: 98-103.

Sattler, J. A. G., I. L. P. Melo, D. Granato, E. Araújo, A. S. Freitas, O. M. Barth, A. Sattler and L. B. Almeida-Muradian. 2015. Impact of origin on bioactive compounds and nutritional composition of bee pollen from Southern Brazil: A screening study. Food Res. Int. 77: 82-91.

Silva, A. S., S. B. Araújo, D. C. Souza and F. A. S. Silva. 2012. Study of the $\mathrm{Cu}, \mathrm{Mn}, \mathrm{Pb}$ and $\mathrm{Zn}$ dynamics in soil plants and bee pollen from the region of Teresina (PI) Brazil. Anais Acad. Bras. Ciên. 84: 881-889.

Singleton, V. L., R. Orthofer and R. M. Lamuela-Raventos. 1999. Analysis of total phenols and other oxidation substrates and antioxidants by means of Folin-Ciocalteu reagent. Method Enzymol. 299: 152-178.

Zhang, L., Y. H. Lin, X. J. Leng, M. Huang and G. H. Zhou. 2013. Effect of sage (Salvia officinalis) on the oxidative stability of Chinese-style sausage during refrigerated storage. Meat Sci. 95: 145-150.

Zuluaga, C., A. Martínez, J. Fernández, J. López-Baldó, A. Quiles and D. Rodrigo. 2016. Effect of high pressure processing on carotenoid and phenolic compounds antioxidant capacity and microbial counts of bee-pollen paste and bee-pollen-based beverage. Innov. Food Sci. Emerg. Technol. 37: 10-17. 